A N N A L E S

UNIVER S T A T IS MARIAE CURIE-SKŁODOW S A LUBLIN - POLONIA

VOL. XXX, 4

SECTIO J

2017

Uniwersytet Marii Curie-Skłodowskiej w Lublinie. Wydział Pedagogiki i Psychologii

\title{
PATRYCJA ZIELIŃSKA
}

patrycja.milosz@wp.pl

\section{Trudności i zagrożenia wynikające z angażowania wolontariuszy $w$ działania pomocowe}

Difficulties and Threats Resulting from Engaging Volunteers in Assistance Activities

\section{STRESZCZENIE}

Artykuł stanowi głos w dyskusji o trudnościach i zagrożeniach związanych z angażowaniem wolontariuszy w działania pomocowe. W opracowaniu przedstawiono teoretyczne ujęcia definicyjne podstawowych zagadnień oraz praktyczne wnioski z obserwacji działań wolontarystycznych. Szczegółowej analizie poddano etapy angażowania wolontariuszy we współpracę z organizacjami pozarządowymi i innymi instytucjami. W każdym stadium aktywności mogą wystąpić problemy wymagające niekiedy natychmiastowej reakcji. Implikacje diagnozy wymienionych przeciwności stanowią podstawę do efektywniejszego planowania i rozwoju działań wolontarystycznych charakteryzowanego sektora. Podjęta tematyka stanowi wkład w uzupełnienie fragmentarycznej wiedzy pragmatycznej o działalności wolontarystycznej w Polsce. Pamiętając, że wolontariat, stanowiąc jednostkowy kapitał ludzki wolontariuszy, sprzyja pomnażaniu ogólnego kapitału społecznego, zasygnalizowany temat powinien stanowić przedmiot dalszych dociekań.

Słowa kluczowe: wolontariat; wolontariusz; praca społeczna

Na miły Bóg,

Życie nie tylko po to jest, by brać. Życie nie po to, by bezczynnie trwać. I, aby żyć, siebie samego trzeba dać.

Stanisław Soyka

WPROWADZENIE

Przemiany społeczno-demograficzne w Polsce, rozpoczęte od okresu transformacji, przyczyniły się także do zmian na gruncie aktywności obywatelskiej. Jak podkreślają P. Gliński i H. Palska (1997, s. 365), owa aktywność wpływa na 
pełnione funkcje obywatelskie przez: 1) artykulację interesów określonej grupy społecznej, 2) kontrolę działań władzy, 3) protest obywatelski, 4) uczestnictwo w procesach przygotowania i podejmowania decyzji na różnych szczeblach władzy, 5) sygnalizowanie problemów i kwestii społecznych, 6) przygotowywanie alternatywnych projektów decyzji, 7) samodzielne zagospodarowanie określonych sfer publicznych - bezpośrednie zaspokajanie potrzeb społecznych itd. Począwszy od lat 90 . ubiegłego stulecia, można zaobserwować dynamiczny rozwój filantropii. Powstaje wiele fundacji, stowarzyszeń bądź innych formalnych i nieformalnych grup mających na celu bezinteresowną pomoc innym ludziom. B. Kromolicka ([red.] 2005, s. 9), dostrzegając intensyfikację działań sektora pozarządowego, które są zorientowane na rozwiązywanie kwestii problemowych w obszarze pomocy społecznej, rozpatruje je jako przejaw etosu opiekuńczego. Ten etos jednostek to:

(...) trwały obyczaj postępowania wyrażającego troskę o innych ludzi [który - P.Z.] ma swoje źródła zarówno w biologicznym instynkcie ludzi, jak i w ich właściwościach duchowych. Jednak celem owego postępowania jest dobro ludzi zawsze skonkretyzowane ich określoną sytuacją życiową. (...) Etos opiekuńczy ma więc wymiar głęboko moralny i duchowy. Wynikające z tego normy życiowe stają się zasadą porządkującą oraz scalającą osobiste działania opiekuńcze (Materne 1999, s. 65).

Współcześnie jedną z popularniejszych, a jednocześnie bezpłatnych form wspomagania działań pomocowych, ukazujących wspomnianą troskę o drugiego człowieka, jest wolontariat. Niekiedy zetknięcie się z prawdziwym nieszczęściem czy dostrzeżenie trudności innych pozwala człowiekowi docenić to, co sam posiada. Praca w wolontariacie, rzetelne wykonywanie nałożonych obowiązków może stać się podstawą do budowania własnej tożsamości, sprawdzania się w różnych rolach i sytuacjach życiowych, zainteresowania się ambitniejszymi kwestiami życia niż własny wygląd czy urojona odwaga. Wolontariat stwarza możliwości podołania wielu wyzwaniom, co konstytuuje wiarę we własne siły. Poza tym tego rodzaju zaangażowanie pozwala na odkrycie radości z dzielenia się tym, czym człowiek sam dysponuje (Segiet 2005, s. 123).

\section{IDEA WOLONTARIATU - WYJAŚNIENIA DEFINICYJNE}

Termin „wolontariat” pochodzi od łac. volontarius, czyli „,dobrowolny, chętny”. Pojęcie volunteering określa „zgłaszanie się na ochotnika”, zaś voluntary service oznacza „służbę, pracę ochotniczą”. Na gruncie polskiej literatury przedmiotu wolontariat jest określany jako „dobrowolna, świadoma, bezpłatna i systematyczna działalność na rzecz innych" (Fabisiak [red.] 2002, s. 5). Za M. Górec$\operatorname{kim}(1999$, s. 335) wolontariat należy zdefiniować jako „bezpłatną, dobrowolną, 
ochotniczą i świadomą pracę stałą bądź okazjonalną na rzecz innych osób spoza kręgu rodzinno-przyjacielsko-koleżeńskiego". W rozumieniu A. Kanios (2010, s. 50) wolontariat stanowi „zróżnicowany ruch społeczny, który można opisać poprzez wskazanie jego istotnych elementów". Autorka podkreśla dobrą wolę i chęć niesienia pomocy, która nie jest podyktowana narzuconymi normami czy chęcią znalezienia pracy. Ponadto zakłada ciągłość oraz systematyczność działań na rzecz potrzebujących. Rozbudowane wyjaśnienie terminu „wolontariat” prezentuje A. Bejma (2012, s. 41-42), dla której stanowi on:

(...) świadomą, bezpłatną, formalną bądź nieformalną działalność społeczną jednostki, nastawioną na zaspokajanie potrzeb społecznych i rozwiązywanie różnorodnych problemów środowiskowych w kraju bądź poza jego granicami, która bezinteresownie, z własnej woli i motywacji, przyjmuje na siebie pośrednią lub bezpośrednią odpowiedzialność poprzez świadczenie pomocy innym ludziom, organizacjom i instytucjom społecznym: fundacjom, stowarzyszeniom, ruchom i komitetom, a także instytucjom kościelnym różnych wyznań w świetle obowiązujących przepisów prawa.

Z punktu widzenia administracyjno-prawnego, powołując się na D. Moroń (2009, s. 38), wolontariat należy postrzegać jako:

(...) ochotnicze i nieodpłatne wykonywanie świadczeń na rzecz określonych podmiotów: organizacji pozarządowych, osób prawnych i jednostek organizacyjnych działających na podstawie przepisów o stosunku Państwa do Kościoła katolickiego w Rzeczypospolitej Polskiej, o stosunku Państwa do innych kościołów i związków wyznaniowych oraz o gwarancjach wolności sumienia i wyznania, jeżeli ich cele statutowe obejmują prowadzenie działalności pożytku publicznego, stowarzyszeń jednostek samorządu terytorialnego, organów administracji publicznej, jednostek organizacyjnych podległych organom administracji publicznej lub nadzorowanych przez te organy, z wyłączeniem prowadzonej przez te jednostki działalności gospodarczej.

Zagadnienie wolontariatu stało się także przedmiotem rozważań Kościoła katolickiego, który za ks. M. Chmielewskim (2002, s. 920) określa go jako „ochotniczą działalność przejawiającą się na rozmaitych płaszczyznach życia społecznego, cechującą się różnym stopniem sformalizowania". Za biskupem J. Chrapkiem (2001, s. 2) należy podkreślić, iż wolontariat „nie jest tylko wyrazem filantropii wobec najbardziej potrzebujących osób, ale jest przede wszystkim sposobem życia, wynikającym z przyjęcia określonych wartości, w których dar z siebie i pomoc bliźniemu stają się miarą człowieczeństwa".

Wyjaśnienia wymaga także określenie pojęcia „wolontariusz”. W ujęciu potocznym wolontariuszem jest człowiek podejmujący się dobrowolnej, pożytecznej działalności, nie oczekując w zamian wynagrodzenia. Inne określenia wolontariusza występujące w literaturze oraz użyciu powszechnym to: ochotnik, społecznik, literacko - siłaczka, doktor Judym, ale niekiedy jest to miano naiwniaka, ,jelenia” czy frajera (Kwapiszewska-Antas, Kwapiszewski 2012). W myśl art. 2 pkt 3 ustawy z dnia 24 kwietnia 2003 r. o działalności pożytku publicznego i o wolonta- 
riacie wolontariuszem jest każda osoba fizyczna, która ochotniczo i bez wynagrodzenia wykonuje świadczenia na zasadach określonych w ustawie. Zatem wolontariuszem może zostać każdy, bez względu na płeć, wiek czy wykształcenie. Są jednak pewne rodzaje działalności, które wymagają pełnoletniości wolontariuszy. $Z$ reguły kandydatom na wolontariuszy nie stawia się żadnych obostrzeń, z wyjątkiem specyficznych działań, które wymagają spełnienia dodatkowych wymogów czy posiadania konkretnych kwalifikacji (np. wobec wolontariuszy zapewniających pomoc medyczną). Jak podkreśla A. Sowiński (2005, s. 98):

(...) ideał osobowy wolontariusza wyrasta z jednej strony z instytucji społecznych, którym państwo i społeczeństwo poprzez swoje wyspecjalizowane służby nie było w stanie zaradzić. Z drugiej zaś strony ma on podłoże psychospołeczne i wyraża się w postaci indywidualnych motywów i aspiracji, jakimi kierują się ludzie, zwłaszcza szczególnie uwrażliwieni na los drugiego człowieka oraz na wartości uniwersalne i transcendentne (...). Poszukując ideału osobowości wolontariusza, idziemy w kierunku rzeczywistości pożądanej, abstrahując od jej stanu aktualnego.

Mimo że nie ma uregulowań prawnych co do oczekiwanych cech wolontariuszy, wskazuje się m.in. na: odpowiedzialność, systematyczność, entuzjazm działania, radość życia, otwartość, kreatywność czy wiarygodność (Włodarczyk 2011). T. Sakowicz (2001, s. 103-104) podkreśla znaczenie: bezinteresownego poświęcania własnych sił dla dobra drugiego człowieka, determinację, wrażliwość, wytrzymałość, umiejętność łączenia współczucia ze sprawnością działania, wyrozumiałość, cierpliwość, dyscyplinę emocjonalną, postawę roztropnej życzliwości oraz umiejętność obracania smutku, złości i innych negatywnych emocji w ,siłę dobra".

Błędem i dużym nieporozumieniem jest redukowanie aktywności wolontariuszy wyłącznie do specyfiki działań charytatywnych czy pomocowych w obrębie pracy socjalnej, ale należy podkreślić, iż ten typ działalności społecznej jest podejmowany stosunkowo najczęściej. Wśród zadań, przed jakimi mogą stanąć wolontariusze, uwzględnia się m.in.:

- pomoc osobom niepełnosprawnym, starszym, chorym, najuboższym, dzieciom,

- pomoc w odrabianiu lekcji i zabawę z dziećmi w świetlicach środowiskowych, ogniskach wychowawczych, domach dziecka,

- pomoc osobom bezrobotnym w znalezieniu pracy,

- pomoc rodzicom w terapii dziecka autystycznego,

- pomoc w rehabilitacji dziecka z porażeniem mózgowym,

- czytanie gazet i książek osobom niewidomym,

- prowadzenie zajęć o różnorodnej tematyce,

- udzielanie wsparcia psychicznego osobom śmiertelnie chorym i uzależnionym oraz ich rodzinom, 
- udzielanie porad psychologicznych i prawnych,

- prowadzenie korespondencji, współtworzenie serwisów internetowych,

- pracę ze zwierzętami,

- pomoc w ochronie środowiska naturalnego,

- udział w kampaniach społecznych, prowadzonych np. przez organizacje ekologiczne czy organizacje zajmujące się prawami człowieka (zbieranie podpisów pod petycjami, przygotowywanie materiałów informacyjnych itp.) (Machniak i in. 2009, s. 129-130).

Jak podkreśla A. Sowiński (2005, s. 95), duże zróżnicowanie kierunków, orientacji oraz praktycznych działań wolontariuszy przysparza trudności w jednoznacznym i spójnym analizowaniu właśnie tego rodzaju działalności ludzkiej. Powołując się na teorie pedagogiki społecznej, należy wyróżnić trzy kategorie możliwych działań wolontariackich. Po pierwsze, może to być działalność bezpośrednia, realizowana w czasie wolnym. Po drugie, należy rozróżnić działalność towarzyszącą pracy zawodowej (np. pielęgniarki, prawnika czy lekarza). Po trzecie, mogą to być zabiegi pośrednie, realizowane przez wybrany i celowo wykorzystywany czynnik obiektywnie istniejący, czyli np. przez sztukę, media lub tworzenie grup wsparcia.

Ustawa z dnia 24 kwietnia 2003 r. o działalności pożytku publicznego i o wolontariacie reguluje obowiązki, jakie muszą zapewnić organizacje społeczne, instytucje państwowe i samorządowe korzystające z pomocy wolontariusza. Do głównych zobowiązań należy zaliczyć zapewnienie wolontariuszom bezpieczeństwa i higieny pracy. Ochotnicy powinni przejść niezbędne szkolenia i powinni być wyposażeni $w$ wiedzę o ryzyku dla zdrowia oraz znać zasady ochrony przed zagrożeniami. Ponadto mają możliwość uzyskania świadczeń zdrowotnych i jest im zapewniane ubezpieczenie od następstw nieszczęśliwych wypadków. Należy podkreślić, że w polskim ustawodawstwie pojęcie wolontariatu na rzecz swoich najbliższych jest możliwe do zastosowania jedynie pod warunkiem zachowania pośrednictwa instytucjonalnego.

Do obowiązków wolontariusza, o których ustawa nie wspomina, a które sygnalizuje E. Wojnowska (2005, s. 151), zalicza się obowiązek zachowania tajemnicy służbowej, czyli wszelkich informacji dotyczących wykonywanej pracy, które są objęte ochroną danych osobowych.

\section{CYKL WSPÓ£PRACY Z WOLONTARIUSZAMI - TRUDNOŚCI I ZAGROŻENIA}

Na podstawie badań Fundacji Pracownia Badań i Innowacji Społecznych „Stocznia” można przedstawić cykl współpracy organizacji z wolontariuszem. Jest on na tyle uniwersalny, że możliwe jest jego transponowanie do placówek każdego typu - bez względu na specyfikę czy liczbę zatrudnionych pracowni- 
ków, ponieważ odnosi się on do podstawowych zasad zarządzania. Cykl ten należy traktować jako zamkniętą całość, a efektywność pracy z wolontariuszami jest zależna od zastosowania wszystkich jego elementów w odniesieniu do konkretnej organizacji bądź instytucji (rys. 1).

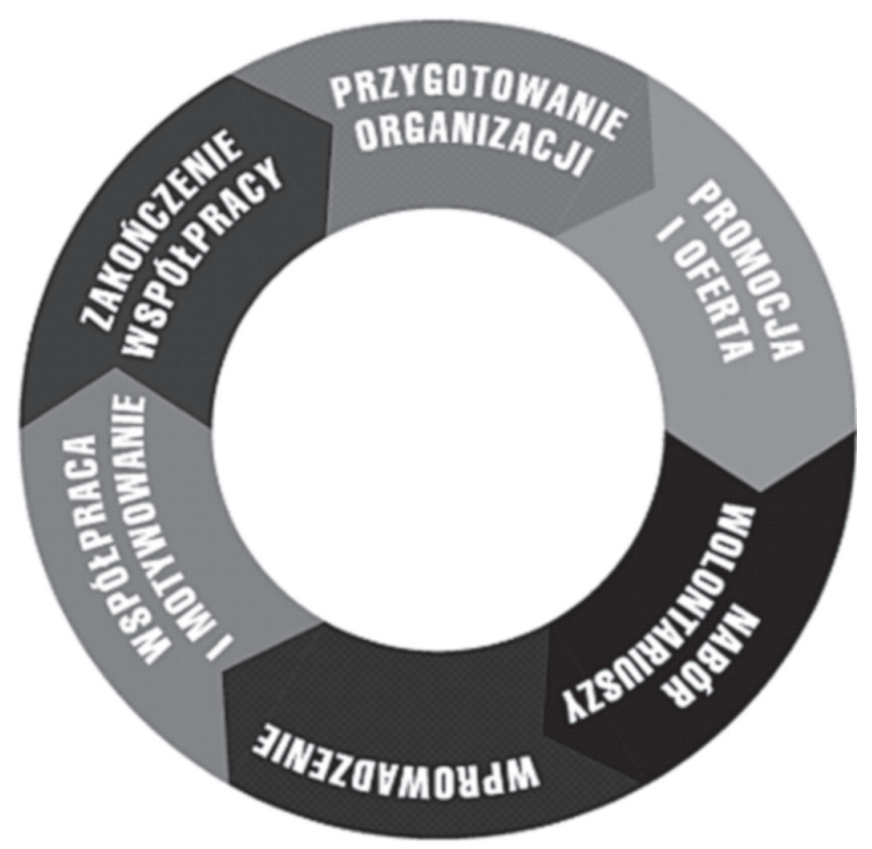

Rys. 1. Cykl współpracy z wolontariuszami

Źródło: (Gortych, Jundziłł, Rustecki 2014, s. 7).

PRZYGOTOWANIE ORGANIZACJI DO PRACY Z WOLONTARIUSZAMI

W pierwszym etapie cyklu, podejmując decyzję o współpracy z ochotnikami, należy dokonać kompleksowej diagnozy. Pojawia się konieczność zidentyfikowania miejsca oraz roli, jaką miałby pełnić potencjalny wolontariusz. Rozpoznania wymagają potrzeby organizacji i czynności, jakie mogłyby być delegowane do zrealizowania przez wolontariusza. Właściwe postępowanie na tym etapie obliguje do doprecyzowania jego roli w organizacji czy instytucji poprzez określenie konkretnych aktywności. Wolontariusz może pełnić rolę edukacyjną, aktywizującą, doradczą, asystencko-pomocniczą i inne, w zależności od specyfiki działań. Angażowanie wolontariuszy wymaga od organizacji często dużego nakładu pracy, czasu i środków. Cała organizacja powinna przygotować się na współpracę, gdyż wolontariusze, mimo że nie są pracownikami etatowymi, stają się częścią zespołu, wspólnie wykonują określone zadania, a tym samym współ- 
tworzą organizację czy instytucję. Na tym etapie istotne są sprawy organizacyjne - począwszy od udostępnienia miejsca i narzędzi pracy, przez wyznaczenie koordynatora działań, po zaznajomienie się z wymogami formalno-prawnymi w kwestii angażowania ochotników.

Już w fazie przygotowawczej mogą pojawić się trudności związane ze współpracą obu podmiotów. Organizacje czy placówki mogą być niedostatecznie przygotowane do spożytkowania potencjału, jakim dysponują wolontariusze. Pojawia się niebezpieczeństwo ograniczania roli wolontariuszy wyłącznie do zadań pomocniczych czy asystenckich, podczas gdy możliwe jest powierzanie im bardziej odpowiedzialnych i ambitnych zadań. Częstym problemem jest właściwe zorganizowanie pracy wolontariuszy przez obłożonych zadaniami członków organizacji. Wolontariusze stają się więc uciążliwością i dodatkowym, często niechcianym obowiązkiem. W takiej sytuacji nie ma również sposobności opracowania sensownego planu rozwoju dla społeczników. Brak struktur organizacyjno-planistycznych może skutkować rozczarowaniem wolontariuszy i spadkiem entuzjazmu do działania. Wolontariusz, który nie jest dobrze „zaopiekowany” przez organizację czy inny podmiot, będzie szukał innej ścieżki zaspokojenia swoich potrzeb, aby nie czuć się zbędnym ogniwem.

\section{OFERTA I PROMOCJA}

Po etapie przygotowania do przyjęcia wolontariusza następuje tworzenie oferty i jej promowanie. Istotnym posunięciem instytucji jest właściwy dobór kanałów przekazu informacji w celu dotarcia do potencjalnych zainteresowanych. Wiele organizacji ma jednak trudności w pozyskiwaniu wolontariuszy, gdyż brak im kompetencji w tym zakresie. Deficyt znajomości metod i strategii rekrutacji skutkuje niepowodzeniem wielu potencjalnych podmiotów. Nieudolność w tym zakresie może być wynikiem niedostosowania form przekazu, które we współczesnym świecie opierają się na nowych technologiach i social mediach, brakiem innowacyjności w całej kampanii promocyjnej lub brakiem wystarczających środków finansowych na jej przeprowadzenie. Duża liczba organizacji współpracujących z wolontariuszami dynamizuje spiralę kreatywnych sposobów dotarcia do nich z przekazem - wymusza pojawienie się zaskakujących form, niespotykanych kanałów, nowatorskich rozwiązań komunikacji marketingowej, w tym zastosowania choćby żartobliwych, lecz wymownych haseł reklamowych. Instytucja, której oferta lub promocja będzie mało atrakcyjna - o ile zostanie dostrzeżona i wysłuchana - nie zainteresuje i nie przekona wolontariuszy do działania.

Interesujące wnioski w aspekcie omawianego zagadnienia prezentuje E. Włodarczyk (2011, s. 38). Zdaniem autorki: 
(...) powszechnie utrzymuje się XIX-wieczne rozumienie wolontariatu jako bezinteresownego poświęcenia na rzecz maluczkich. Tak bardzo wąskie pojmowanie wolontariatu skutkuje wąskim zasięgiem pozyskiwania wolontariuszy, strategią promowania i komunikowania oraz typem działań, które są kwalifikowane jako wolontariat. Ma to także dwie ważne konsekwencje. Po pierwsze - blokuje podejmowanie działań na rzecz zbudowania podstaw wolontariatu w postaci wprowadzenia go w curriculum uczelniane, sieciowania się z innymi inicjatywami itp. Po drugie - odstrasza od wolontariatu ludzi, którzy chcieliby zrobić coś dla innych, ale niekoniecznie w atmosferze poświęcania się, i niekoniecznie wyłącznie dla osób pokrzywdzonych przez los, ale dla osób, które po prostu czegoś pragną.

\section{NABÓR WOLONTARIUSZY}

Wybór właściwego wolontariusza do organizacji determinuje późniejszy sukces w wypełnianiu przewidzianych działań, a tym samym zadowolenie wszystkich stron. Można zakładać, że odpowiednio przeprowadzony proces promocyjny znajdzie odpowiedź wśród ludzi, którzy spełnią oczekiwania instytucji. Efektywna selekcja wolontariuszy powinna uwzględniać angażowanie zróżnicowanych grup, uwzględniających np. różny przedział wiekowy, zainteresowania bądź doświadczenia i oferowanie im programów/zadań dostosowanych do możliwości, a jednocześnie będących odpowiedzią na ich potrzeby. Podkreślić należy, iż w oparciu o teorię Maslowa wolontariat zaspokaja potrzeby wyższego rzędu, tj. np. potrzebę pomagania innym, poznania zawodu, podzielenia się wiedzą, doświadczeniem bądź energią. Zachowania prospołeczne mogą być podyktowane m.in.:

- motywacją altruistyczną: potrzebą dopełnienia wartości własnego życia bezinteresowną pracą dla innych,

- motywacją zadaniową: dotyczy doświadczenia i powinności zadaniowych, neutralizowania niedostatku oraz bezduszności profesjonalnej opieki medycznej,

- motywacją ideologiczną: związaną z przeżyciem religijnym, rodzinnymi wzorami służby społecznej,

- motywacją egoistyczną: potrzebą sprawdzenia się, dorównania innym, pozyskania nowych umiejętności umożliwiających zdobycie pracy, podniesienia swojego prestiżu w oczach osób trzecich,

- motywacją afiliacyjną: wynikającą z potrzeby kontaktu z innymi ludźmi bądź całego środowiska jednostek podobnie myślących i odczuwających (Segiet 2005, s. 118-119).

Aktywność wolontariacka należy do tego rodzaju zachowań ludzkich, których mechanizm ma charakter polimotywacyjny, co oznacza, że działanie jest zdeterminowane hierarchią motywów, na które wpływa struktura osobowości, sytuacja, etap biografii, a niekiedy również środowisko społeczne (Górecki 1999, s. 335-336). 
$\mathrm{Na}$ etapie naboru wolontariuszy mogą wystąpić trudności o różnej specyfice. Przede wszystkim istnieje ryzyko braku odzewu ze strony wolontariuszy. Brak chętnych czy znikome zainteresowanie wolontariatem może wpłynąć na decyzję o przyjęciu wszystkich potencjalnych kandydatów. Może wystąpić także sytuacja odwrotna, czyli zbyt duże zainteresowanie działaniami organizacji, które wymuszają konieczność przeprowadzenia selekcji i asertywnej odmowy. Pojawia się zagrożenie, że zostaną przyjęte niewłaściwe osoby - takie, które mają zbyt duże ograniczenia czasowe, niewystarczające doświadczenie lub umiejętności. Na każdym etapie rekrutacji, a niekiedy też po pierwszych akcjach pomocowych, może zaistnieć konieczność podziękowania osobie za zaangażowanie. Jak podkreślają praktycy, odmowa nie należy do sytuacji przyjemnych, poza tym może wpłynąć demotywująco na osobę oferującą wolny czas i zapał do darmowej pracy. Istotne są wtedy kluczowe umiejętności komunikacyjne (np. koordynatora wolontariatu).

\section{WPROWADZENIE WOLONTARIUSZY}

Jest to szczególny i niekiedy niełatwy moment zarówno dla samych wolontariuszy, jak i organizacji. Charakteryzuje się niepewnością oraz zagubieniem. Na tym etapie może pojawić się trudność w budowaniu wzajemnego zaufania i poczucia więzi tak z instytucją, jak i pozostałymi członkami zespołu. Poznanie i otwarcie się na wolontariuszy jest ważne z uwagi na konstruowanie właściwej, przyjaznej atmosfery pracy, a także statusu wolontariusza jako pełnoprawnego członka zespołu. Proces adaptacji wolontariusza wymaga cierpliwości i życzliwości ze strony pozostałych członków organizacji. Już na początku należy określić panujące zasady. Jest to związane również z koniecznością sformalizowania pracy wolontariackiej umową. Pisemne porozumienie, wymagane przy okresie współpracy powyżej 30 dni, stanowi umowę o charakterze cywilno-prawnym, nie jest umową stosunku pracy.

\section{WSPÓŁPRACA I MOTYWOWANIE WOLONTARIUSZY}

Etap współpracy właściwej może przysparzać trudności dwojakiego rodzaju. Wymaga on sprawnej organizacji i nadzorowania prac wolontariuszy. Spośród pracowników instytucji powinna być wyłoniona osoba odpowiedzialna za koordynację pojedynczego ochotnika lub całej grupy wolontariuszy. Do zadań koordynatora wolontariatu należy m.in.:

- zidentyfikowanie potrzeb organizacji,

- prowadzenie spotkań i naboru wolontariuszy,

- pilnowanie kwestii formalnych (porozumienie o współpracy, ubezpieczenie), 
- zapoznanie z kulturą organizacyjną (opowiedzenie, gdzie i kiedy spotyka się zespół pracowników, jakie panują zwyczaje w kuchni lub zasady sprzątania itp.),

- przygotowanie miejsca pracy i niezbędnych narzędzi,

- zaplanowanie i zorganizowanie szkoleń lub innych form przygotowania do zadań,

- wdrożenie i przygotowanie wolontariuszy do zadań,

- opracowanie harmonogramów zadań,

- nadzorowanie pracy wolontariuszy,

- dbanie o rozwój wolontariuszy,

- dbanie o dobre relacje w grupie oraz twórczą atmosferę pracy,

- motywowanie i nagradzanie wolontariuszy,

- przeprowadzanie spotkań okresowych i podsumowujących,

- ewaluacja pracy wolontariuszy (Gortych, Jundziłł, Rustecki 2014, s. 14).

Dobry koordynator jest na wagę złota. To osoba, która jest w pierwszym kontakcie z wolontariuszami - to ona się z nimi komunikuje, jest odpowiedzialna za reagowanie w sytuacjach konfliktowych czy kryzysowych, włącznie z nagłym opuszczeniem wolontariatu. W kwestii organizacyjnej należy pamiętać, że związek wolontariuszy z placówką jest znacznie słabszy niż w przypadku pracowników. Niekiedy występuje niemal ciągła rotacja społeczników, która niewątpliwie zakłóca organizację, porządek i dotychczasową systematyczność wykonywanych prac. Nowi wolontariusze mogą przejawiać niechęć do współpracy z innymi członkami zespołu, która może być konsekwencją konfliktów na tle różnych punktów widzenia czy odmiennych metod pracy.

Drugą trudnością jest konieczność nieustannego motywowania wolontariuszy, co leży w gestii nie tylko koordynatora, ale i pozostałych członków organizacji czy instytucji. Początkowy zapał i energia do „naprawiania świata” przez wolontariuszy w zderzeniu z realiami codzienności bardzo często słabnie. M. Czerepaniak-Walczak (2005, s. 164) podkreśla istotne znaczenie występowania pułapek, na które są narażone osoby miłosierne, w tym wolontariusze. Autorka zwraca uwagę na niebezpieczeństwo związane z: 1) poczuciem własnej hojności, a niekiedy nawet wspaniałości (pycha, nierzadko nieuświadomiona), 2) rozczarowaniem w wyniku braku wdzięczności ze strony obdarowanych, 3) naiwnością, bezpodstawną wiarą $\mathrm{w}$ to, co mówią oczekujący pomocy, 4) wyrzutami sumienia w sytuacji niemożności zaspokojenia wszystkich oczekiwań (zarówno realnych, jak i wygórowanych), poczuciem własnej nieodpowiedniości w obliczu wypełnienia określonych zadań pomocowych. Wewnętrzna motywacja może zostać nadwyrężona także pod wpływem nieumiejętnego zarządzania pracą, arogancji członków zespołu, niekomfortowej atmosfery pracy, ignorowania efektów pracy wolontariuszy, często też niedoceniania ich wysiłków. Konieczność uzyski- 
wania wskaźników i konkretnych efektów działań wolontariackich stwarza niebezpieczeństwo zachęcania wolontariuszy do jeszcze większego zaangażowania i wydajności pracy, przy jednoczesnym pominięciu aspektu nagradzania ich aktywności oraz wkładu w rozwój organizacji. Ten aspekt gratyfikacji, przy choćby najmniej ważnych czy odpowiedzialnych zadaniach, wpływa na motywację do dalszej ochotniczej pracy. Niekiedy trudnością organizacji jest odpowiednie dobranie środków motywacyjnych. Cały system motywacji powinien być przemyślany i właściwie dobrany do wolontariusza. Nietrafiony rodzaj nagrody nie przyniesie żadnych korzyści ani wolontariuszowi, ani organizacji. Ponadto procedura motywacji powinna odzwierciedlać możliwości instytucji. Często bywa tak, że analizowane jest $\mathrm{z}$ jednej strony zapotrzebowanie np. na szkolenie będące formą motywowania, zaś z drugiej - koszty jego organizacji. Decyzje w tym względzie często nie należą do łatwych i przyjemnych.

\section{ZAKOŃCZENIE WSPÓŁPRACY}

To nieunikniony etap współdziałania wolontariusza z organizatorem wolontariatu. Może być wywołany zarówno zakończeniem projektu czy pewnego etapu działań, jak i rezygnacją lub koniecznością usunięcia tzw. trudnego wolontariusza. We wszystkich wymienionych sytuacjach, bez względu na okoliczności i powody rozstania, wymagany jest wzajemny szacunek. Szczególnie trudna bywa sytuacja rozwiązania współpracy z wolontariuszem, który np. nie przestrzega zasad, łamie regulaminy i jest osobą konfliktową. Mimo że często ujawniają się wtedy negatywne emocje, od organizacji wymaga się profesjonalnego podejścia, które uwidacznia się kulturalną atmosferą separacji. Należy pamiętać o konieczności podziękowania i podsumowania całokształtu działań wolontariusza. Pojawia się również konieczność poświadczenia jego zaangażowania. Brak wymagań w kwestii precyzyjnych zapisów poświadczających zdobyte umiejętności i kompetencje podczas posługi wolontariackiej niekiedy sprowadza się tylko do poświadczenia statusu wolontariusza, co potencjalnemu pracodawcy nie uświadamia zalet pozyskanych w pracy ochotniczej.

Trudności związanych $\mathrm{z}$ angażowaniem do pracy na zasadzie wolontariatu należy poszukiwać także w ogólnospołecznym braku zaufania do organizacji pozarządowych. Jak wynika z badań, niemal połowa (48\%) Polaków ufa organizacjom pozarządowym, ale sytuacja jest daleka od ideału, gdyż brak ufności np. wobec fundacji deklaruje $28 \%$ ankietowanych, zaś wobec stowarzyszeń $-31 \%$ (Adamiak 2015). Taki stan rzeczy może mieć związek choćby z nagłośnionymi nadużyciami w tego rodzaju działalności.

Innego typu demotywatorem w pracy wolontariackiej może być fakt, że wolontariusze, którzy podjęli się dobrowolnej pracy bez wynagrodzenia z chęci zdo- 
bycia doświadczenia zawodowego, a w dalszej perspektywie uzyskania dodatkowych atutów na rynku pracy, doznali przykrego rozczarowania. W procesie rekrutacji do pracy zawodowej pracodawcy przejawiają niekiedy ostrożne lub nawet sceptyczne zaufanie do doświadczeń wolontariackich.

Z badań GUS (2016) wynika, że wolontariuszami są głównie ludzie młodzi. Wraz z wiekiem odsetek wolontariuszy się obniża. Być może brakuje pomysłów na zagospodarowanie ludzi starszych jako potencjalnie aktywnej grupy wolontariuszy, która przejawia dyspozycyjność czasową i silną potrzebę bycia potrzebnym (Włodarczyk 2011).

Można sądzić, że trudność w dotarciu do określonych osób czy grup ludzi młodych może wynikać z faktu, iż niektórym dalekie są postawy prospołeczne, mają niewystarczającą wrażliwość oraz gotowość niesienia pomocy innym. Nadal niektórzy bardziej cenią „mieć”, niż „być”. Sytuacja społeczno-gospodarcza kraju, w którym wciąż panują zasady wyścigu i rywalizacji, nie sprzyja docenianiu i rozwojowi wartości altruistycznych.

\section{ZAKOŃCZENIE}

Konkludując, należy podkreślić, że:

(...) najważniejszą dziedziną, w której człowiek może coś dać drugiemu człowiekowi, nie jest sfera rzeczy materialnych, lecz ściśle ludzkich. Co daje jeden człowiek drugiemu? Daje z siebie to, co jest w nim najcenniejsze, daje swoje życie. Nie musi to oczywiście oznaczać, że poświęca swoje życie dla drugiego człowieka, lecz że daje mu to, co jest w nim żywe, daje swoją wiedzę, humor i swój smutek. (...) W ten sposób, dając swoje życie, wzbogaca drugiego człowieka, wzmaga poczucie jego istnienia (Fromm 1994, s. 30-31).

Ogólny trend w sferze rozwoju gospodarczego oraz globalizacji, przy jednoczesnej dynamicznej stymulacji do wzrostu roli podmiotów non-profit, powinien skłaniać badaczy do zgłębiania pożądanych i niepożądanych symptomów rzeczywistości wpływających na specyfikę wolontariatu, kształtowania postaw i zachowań prospołecznych ludzi. Zaprezentowanie niniejszych dywagacji stanowi zaproszenie do dyskusji nad wszelkimi zagrożeniami w działaniach wolontariackich, które mogą hamować rozwój wolontariatu i jego idei. Precyzyjna diagnoza w tym zakresie może przyczynić się do wypracowania rozwiązań - metod i narzędzi praktycznego współdziałania z wolontariuszami. 


\section{BIBLIOGRAFIA}

Adamiak P. (2015), Wizerunek organizacji pozarzadowych. Raport z badania, Warszawa: Stowarzyszenie Klon/Jawor.

Bejma A. (2012), Wolontariat w Polsce i w Europie Środkowo-Wschodniej. Prawo i praktyka, Warszawa: Oficyna Wydawnicza ASPRA-JR.

Chmielewski M. (2002), Leksykon duchowości katolickiej, Kraków-Lublin: KUL.

Chrapek J. (2001), Dzielmy się miłością, Radom: List.

Czerepaniak-Walczak M. (2005), Od pomocy państwa do samopomocy - procesy emancypacji w spoleczeństwie obywatelskim (perspektywa pedagogiczna), [w:] B. Kromolicka (red.), Wolontariat w obszarze humanistycznych wyzwań opiekuńczych, Toruń: Wydawnictwo Edukacyjne Akapit.

Fabisiak J. (red.) (2002), Młodzieżowy wolontariat, Warszawa: Fundacja Świat na Tak.

Fromm E. (1994), O sztuce mitości, Warszawa: Dom Wydawniczy Rebis.

Gliński P., Palska H. (1997), Cztery wymiary społecznej aktywności obywatelskiej, [w:] H. Domański, A. Rychard (red.), Elementy nowego tadu, Warszawa: Wydawnictwo IFiS PAN.

Gortych D., Jundziłł I., Rustecki W. (2014), Praktyczny poradnik współpracy z wolontariuszami. Zasady organizacji przyjaznej wolontariuszom, Warszawa: Fundacja Pracownia Badań i Innowacji Społecznych Stocznia.

Górecki M. (1999), Wolontariat, [w:] D. Lalak, T. Pilch (red.), Elementarne pojęcia pedagogiki spotecznej i pracy socjalnej, Warszawa: Wydawnictwo Akademickie Żak.

GUS (2016), Wolontariat w organizacjach - $2016 r$. Wstępne wyniki badań „Praca niezarobkowa poza gospodarstwem domowym", Warszawa.

Kanios A. (2010), Społeczne kompetencje studentów do pracy w wolontariacie, Lublin: Wydawnictwo UMCS.

Kromolicka B. (red.) (2005), Wolontariat w obszarze humanistycznych wyzwań opiekuńczych, Toruń: Wydawnictwo Edukacyjne Akapit.

Kwapiszewska-Antas M., Kwapiszewski J. (2012), Polityka społeczna, praca socjalna i wolontariat, Piła: Państwowa Wyższa Szkoła Zawodowa im. Stanisława Staszica.

Machniak M., Strzelczyk E., Walz D., Woś M. (2009), Wiedza studentów Wszechnicy Świętokrzyskiej na temat działalności wolontariackiej, [w:] B. Matyjas (red.), Wolontariat jako działanie prospołeczne w obszarze pomocy społecznej i pracy socjalnej, Kielce: Wszechnica Świętokrzyska.

Materne J. (1999), Pedagogika socjalna: systematyzacja zagadnień i pojęć, Szczecin: Wydawnictwo Mater.

Moroń D. (2009), Wolontariat w trzecim sektorze. Prawo i praktyka, Wrocław: Wydawnictwo Uniwersytetu Wrocławskiego.

Sakowicz T. (2001), Wolontariat $w$ stużbie rodzinom dysfunkcjonalnym, [w:] J. Śledzianowski (red.), Wolontariat z pomoca rodzinie z uzależnieniami, Kielce: Zakład Profilaktyki Społecznej i Resocjalizacji Wydziału Pedagogicznego Akademii Świętokrzyskiej.

Segiet K. (2005), Znaczenie wolontariatu działającego na rzecz dzieci i młodzieży w różnych obszarach życia spolecznego, [w:] B. Kromolicka (red.), Wolontariat w obszarze humanistycznych wyzwań opiekuńczych, Toruń: Wydawnictwo Edukacyjne Akapit.

Sowiński A. (2005), W poszukiwaniu ideału osobowości wolontariusza, [w:] B. Kromolicka (red.), Wolontariat w obszarze humanistycznych wyzwań opiekuńczych, Toruń: Wydawnictwo Edukacyjne Akapit.

Ustawa z dnia 24 kwietnia 2003 r. o działalności pożytku publicznego i o wolontariacie (Dz.U. 2003, nr 96, poz. 873).

Włodarczyk E. (2011), Odcienie i cienie wolontariatu, „Kultura i Edukacja”, nr 3. 
Wojnowaka E. (2005), Wybrane aspekty prawne wolontariatu [w:] B. Kromolicka (red.), Wolontariat w obszarze humanistycznych wyzwań opiekuńczych, Toruń: Wydawnictwo Edukacyjne Akapit.

\section{SUMMARY}

The article is a voice in the discussion on difficulties and threats related to the involvement of volunteers in assistance activities. It presents theoretical definitions of basic issues as well as practical conclusions from the observation of voluntary activities. The stages of engaging volunteers in cooperation with non-governmental organizations or other institutions have been analyzed in detail. At any stage of the activity, problems may arise that require immediate reaction. The implications of diagnosing these adversities are the basis for more effective planning and development of volunteer activities in the sector. The subject matter is a contribution to complementing the fragmented pragmatic knowledge of voluntary activity in Poland. Bearing in mind that volunteering by providing individual human capital of volunteers favors the multiplication of general social capital, the signaled topic should be the subject of further inquiries.

Keywords: volunteering; volunteer; social work 